\title{
The biogenesis of iron-sulfur proteins: from cellular biology to molecular aspects
}

\author{
Mario Piccioli ${ }^{1}$
}

Published online: 10 April 2018

(c) SBIC 2018

When the Journal of Biological Inorganic Chemistry began its publication, the title of the first article in Issue 1, 1996 told us all about the hottest topics and sexiest perspectives of the pre-genomic era: "The coordination sphere of iron-sulfur clusters: lesson from site-directed mutagenesis experiments" [1]. The newborn Society of Biological Inorganic Chemistry wanted a journal that could strengthen the cultural identity of the biological inorganic chemistry community, offering not only the opportunity to present research contributions in a dedicated journal but also to create a forum for critical assessment and open discussion. Indeed, in Issue 2, this idea took the form of a series of commentaries written by some of the leading scientists in a specific field. A preliminary version of each commentary was circulated among the other contributors, and the final versions were collected shortly thereafter. The outcome was a series of contributions addressing a given topic from different points of view and giving rise to a stimulating debate. Guess what the first argument was? Oh yes, "Exchange vs double exchange in polymetallic $\mathrm{Fe}-\mathrm{S}$ systems" [2-7]!

In the new millennium, the focus of $\mathrm{Fe}-\mathrm{S}$ protein research quickly moved from the biophysical and structural properties of small electron transfer proteins to the study of $\mathrm{Fe}-\mathrm{S}$ clusters containing enzymes and biosynthetic pathways generating $\mathrm{Fe}-\mathrm{S}$ proteins in model organisms and in humans. A new generation of microbiologists, cell and molecular biologists, and eventually geneticists entered into the scenario, moving the frontier in $\mathrm{Fe}-\mathrm{S}$ protein research from a biophysically oriented approach toward a novel, translational perspective $[8,9]$. In-cell studies, mouse models, and yeast-two hybrid assays took on the role played 20 years before by EPR, Mössbauer, and NMR spectroscopies, contributing to our

Mario Piccioli

piccioli@cerm.unifi.it

1 Department of Chemistry, Magnetic Resonance Center CERM, University of Florence, Via Luigi Sacconi 6, Sesto Fiorentino, 50019 Florence, Italy understanding of the biogenesis mechanisms of iron-sulfur clusters and addressing their relevance to human diseases.

Given the above, the biogenesis of $\mathrm{Fe}-\mathrm{S}$ proteins is a fantastic playground for gathering together genetics, cell biology, integrated structural biology, metalloproteomics, and spectroscopy to form a unique research platform that provides a molecular view of $\mathrm{Fe}-\mathrm{S}$ protein assembly processes and trafficking pathways as well as an understanding of pathophysiological mechanisms underlying human diseases related to $\mathrm{Fe}-\mathrm{S}$ protein biogenesis. The opportunity to use this concept in an ongoing project came from the Association for European Cooperation in Science and Technology (COST), the oldest European framework supporting transnational cooperation among researchers across Europe. COST Action 15133, The Biogenesis of Iron-Sulfur Proteins: From Cellular Biology to Molecular Aspects (FesBioNet) began on May 1, 2016. The Action will build a network of differing competences and infrastructures that will support early career investigators and research groups from European inclusiveness-target countries, frame the research of individual groups within broader scenarios, and achieve scientific deliverables that could not be reached without knowledge- and infrastructure-sharing-based approaches.

This COST Action, moreover, constitutes a unique opportunity to survey the state of the art from many different perspectives. Not surprisingly, most of the Action Management Committee members are well aware of the liaison that has, for more than 20 years, existed between JBIC and Fe-S proteins. We, therefore, have asked some of the European scientists involved in the Action to provide a contribution to this JBIC Topical Issue.

This issue begins by discussing the links between human diseases and cellular $\mathrm{Fe}-\mathrm{S}$ assembly machineries and proceeds toward assembly and maturation processes via signaling pathways involving mitochondria and cystosol as well as underlying molecular mechanisms. Later contributions present structural and functional properties for some specific 
cases and address the biophysics and the interactomics of $\mathrm{Fe}-\mathrm{S}$ proteins and $\mathrm{Fe}-\mathrm{S}$ biogenesis.

Rudy Van Coster and Arnaud Vanlander, from the Gent University Hospital, provide, from a medical doctor's standpoint, a review of clinical and genetic aspects of defects associated with the synthetic pathway of $\mathrm{Fe}-\mathrm{S}$ clusters [10], while Kostas Tokatlidis and colleagues, from the Institute of Molecular, Cell and System Biology of the University of Glasgow, review, from chemistry to disease, the recent discoveries in both the yeast and human iron sulfur cluster arena [11]. From the Institute of Parasitology in CeskeBudejovice, Julius Lukes and coauthor Priscilla Pena-Diaz address the role of $\mathrm{Fe}-\mathrm{S}$ cluster assembly processes in pathogenic protists of medical importance [12]. As many metabolic processes occurring in chloroplasts depend on the maturation of $\mathrm{Fe}-\mathrm{S}$ proteins, plant physiologist and biochemist Nicholas Rouhier and coworkers, from the University of Lorraine, offer an extensive review on currently known molecular details concerning the assembly and roles of $\mathrm{Fe}-\mathrm{S}$ proteins in plastids [13]. Molecular chaperones take a fundamental role in the assembly of mitochondrial $\mathrm{Fe}-\mathrm{S}$ proteins [14], as described in the contribution from Rafal Dutkiewicz and Malgorzata Nowak from the biotechnology faculty of the University of Gdansk, while a close-up view of the molecular mechanism in $\mathrm{Fe}-\mathrm{S}$ cluster biogenesis [15] is offered, in the case of the bacterial SUF machinery, by Sandrine Ollagnier and Julien Perard, from Commisariat pour l'Energie Atomique (CEA) in Grenoble.

The peculiar structural features of NEET proteins, a class of $2 \mathrm{Fe}-2 \mathrm{~S}$ proteins of growing interest in health and disease, are presented by Rachel Nechustai and coworkers from the Hebrew University of Jerusalem [16]. The maturation of mixed $\mathrm{Ni}-\mathrm{Fe}-\mathrm{S}$ clusters is also discussed in the case of the C-cluster of carbon monoxide dehydrogenase by the Christophe Léger group, from the French National Research Council (CNRS) laboratories in Marseille [17].

The first sign of the existence of iron-sulfur proteins came to us from an EPR signal. Aspects associated with the evolution from in vitro to in vivo EPR studies of $\mathrm{Fe}-\mathrm{S}$ proteins are discussed by Fred Hagen from Delft University of Technology [18]. Again, from in vitro to in vivo, the relationship between $\mathrm{Fe}-\mathrm{S}$ proteins and Mössbauer spectroscopy is addressed by Genevieve Blondin and coworkers, from CEA Grenoble, aiming to illustrate how Mössbauer spectroscopy contributes to help unravel the steps in $\mathrm{Fe}-\mathrm{S}$ cluster biogenesis [19]. Resonance Raman Spectroscopy as a sensitive tool to address cluster type, symmetry, and redox properties of $\mathrm{Fe}-\mathrm{S}$ clusters in proteins is summarized by Smilja Todorovic and Miguel Teixeira from the Antonio
Xavier Research Institute of the Universidade Nova de Lisboa [20]. Finally, NMR contributions to our understanding of the electronic structure of iron-sulfur proteins and of the interactomics of their assembly processes are addressed by Lucia Banci and the CERM group in Florence [21].

As a closing remark, let me express my warmest thanks and my deepest gratitude to Chief Editor Larry Que for agreeing to host this series of articles in JBIC, to Debbie Schoenholz from the JBIC Editorial Office for being incredibly patient and efficient in tutoring me as Guest Editor, and to all reviewers for their timely responses. Finally, congratulations and thanks to all the contributors who accepted my invitation and provided such excellent manuscripts.

\section{References}

1. Moulis J-M, Davasse V, Golinelli M-P, Meyer J, Quinkal I (1996) J Biol Inorg Chem 1:2-14

2. Luchinat C (1996) J Biol Inorg Chem 1:169

3. Blondin G, Girerd J-J (1996) JBIC 1:170-172

4. Kröckel M, Grodzicki M, Papaefthymiou V, Trautwein AX, Kostikas A (1996) JBIC 1:173-176

5. Noodleman L, Case DA, Mouesca J-M, Lamotte B (1996) JBIC 1:177-182

6. Bertini I, Luchinat C (1996) J Biol Inorg Chem 1:183-185

7. Belinskii MI (1996) JBIC 1:186-188

8. Rouault TA, Tong WH (2008) Trends Genet 24:398-407

9. Lill R (2009) Nature 460:831-838

10. Vanlander A, Van Coster R (2018) J Biol Inorg Chem 23:3. https ://doi.org/10.1007/s00775-018-1550-z

11. Cardenas-Rodriguez M, Chatzi, Tokatlidis K (2018) J Biol Inorg Chem 23:3. https://doi.org/10.1007/s00775-018-1548-6

12. Pena-Diaz P, Lukes J (2018) J Biol Inorg Chem 23:3. https://doi. org/10.1007/s00775-018-1556-6

13. Przybyla-Toscano J, Roland M, Gaymard F, Couturier J, Rouhier N (2018) J Biol Inorg Chem 23:3. https://doi.org/10.1007/s0077 5-018-1532-1

14. Dutkiewicz R, Nowak M (2018) J Biol Inorg Chem 23:3. https:// doi.org/10.1007/s00775-017-1504-X

15. Ollagnier-de Choudens S, Pérard J (2018) J Biol Inorg Chem 23:3. https://doi.org/10.1007/s00775-017-1527-3

16. Karmi O, Marjault H-B, Pesce L, Carloni P, Onuchic J, Jennings P, Mittler R, Nechushtai R (2018) J Biol Inorg Chem 23:3. https ://doi.org/10.1007/s00775-018-1538-8

17. Merrouch M, Benvenuti M, Lorenzi M, Léger C, Fourmond V, Dementin S (2018) J Biol Inorg Chem 23:3. https://doi. org/10.1007/s00775-018-1541-0

18. Hagen WR (2018) J Biol Inorg Chem 23:3. https://doi. org/10.1007/s00775-018-1543-y

19. Garcia-Serres R, Clemancey M, Latour JM, Blondin G (2018) J Biol Inorg Chem 23:3. https://doi.org/10.1007/s00775-018-1534-Z

20. Todorovic S, Teixeira M (2018) J Biol Inorg Chem 23:3. https:// doi.org/10.1007/s00775-018-1533-0

21. Banci L, Camponeschi F, Ciofi-Baffoni S, Piccioli M (2018) J Biol Inorg Chem 23:3. https://doi.org/10.1007/s00775-018-1552-x 